\title{
Acute Fatty Liver of Pregnancy in a Woman with Type 2 Diabetes
}

\section{Kwang-Wen Chen ${ }^{1 *}$, Cherng-Chia Yang ${ }^{2}$, Yuan-Ming Li ${ }^{3}$ and Yuan-Shun Lee ${ }^{4}$}

${ }^{1}$ Department of Internal Medicine, St Paul's Hospital, Taiwan

${ }^{2}$ Department of Obstetrics and Gynaecology, St Paul's Hospital, Taiwan

${ }^{3}$ Department of Laboratory, St Paul's Hospital, Taiwan

${ }^{4}$ Department of Pediatrics, St Paul's Hospital, Taiwan

\begin{abstract}
We report a 35 year-old woman with type 2 diabetes who developed acute fatty liver of pregnancy in her 35th week of pregnancy. She presented with nausea, vomiting, elevated transaminases, elevated bilirubin, renal impairment, and coagulopathy. Her condition improved dramatically after an emergency cesarean section.
\end{abstract}

Keywords: Acute fatty liver of pregnancy; Diabetes mellitus

\section{Introduction}

Acute Fatty Liver of Pregnancy (AFLP) is a rare life-threatening complication of pregnancy. The estimated incidence of AFLP was 5 cases per 100,000 pregnancies and case fatality rate was $1.8 \%$ in a prospective study [1]. Reported maternal mortality has ranged from none to $11 \%$ [2-4]. Non-alcoholic Fatty Liver (NAFL) is very common in type 2 diabetes [5]. However, the occurrence of AFLP in type 2 diabetes has not been previously reported. AFLP occurring in women with diabetes could be very dangerous. We report a rare case of AFLP in a woman with type 2 diabetes and raise an issue on the linkage between type 2 diabetes and AFLP with a brief literature review.

\section{Case Report}

A 35-year-old woman in her 35th week of pregnancy was hospitalized via the emergency department with nausea, vomiting, and malaise for 1 week in February 2011. She had been diagnosed as type 2 diabetes in January 2010 with fasting sugar $245 \mathrm{mg} / \mathrm{dl}, \mathrm{Hb}$ Alc 9.9\% (HPLC 4.3 - 6.5\%), and C-peptide $1.38 \mathrm{nmol} / \mathrm{l}$ (normal 0.9-4.0 $\mathrm{nmol} / \mathrm{l})$. Her body height was $160 \mathrm{~cm}$, weight $58 \mathrm{~kg}$, Body Mass Index (BMI) $22.6 \mathrm{~kg} / \mathrm{m}^{2}$ and blood pressure $122 / 87 \mathrm{mmHg}$. Her mother has type 2 diabetes under oral hypoglycemic agent treatment. Her younger brother and sister are well without other autoimmune disease. Although Latent Autoimmune Diabetes in Adult (LADA) is possible, we cannot prove it without islet autoantibodies. Since then, she had been treated with premixed insulin in preparing for a planned pregnancy which was diagnosed in June 2010, her last menstrual period having occurred in May. A1C levels were $7.4 \%$ and $7.3 \%$ in July and September. She was doing well until 1 week before visiting the emergency department due to persistent symptoms despite prior visits to the obstetrical and medical outpatient clinics. On physical examination, she was alert, appeared ill, and not icteric. Laboratory data were aspartate aminotransferase (AST) $550 \mathrm{U} / \mathrm{l}$ ( normal 0-35 U/1), alanine aminotranferease (ALT) $651 \mathrm{U} / \mathrm{l}$ (normal 0 - $32 \mathrm{U} / \mathrm{l}$ ), alkaline phosphatase (ALP) $1106 \mathrm{U} / \mathrm{l}$ ( normal 125 - $250 \mathrm{U} / \mathrm{l}$ ), LDH 218 (normal 98 - $192 \mathrm{U} / \mathrm{l}$ ) total bilirubin (T Bil) $1.4 \mathrm{mg} /$ dl (normal $0.2-1.2 \mathrm{mg} / \mathrm{dl}$ ) , creatinine (Cr) $1.39 \mathrm{mg} / \mathrm{dl}$ (normal $0.8-1.3$ $\mathrm{mg} / \mathrm{dl}$ ), activated partial thrombin time (APTT) $39.4 \mathrm{~s}$ (normal $28.2 \mathrm{~s}$ ) and prothrombin time (PT) $13.1 \mathrm{~s}$ (normal $10 \mathrm{~s}$ ), Viral hepatitis A, B, and $\mathrm{C}$ were excluded by negative results for anti-HAV IgM, HBsAg, and anti-HCV Ab. Gallbladder stones were shown with abdominal ultrasound.

After hospitalization, diabetes insipidus was also diagnosed and treated with DDAVP for a short period. Her condition progressively deteriorated with elevated levels of $\mathrm{Cr}$ to $1.53 \mathrm{mg} / \mathrm{dl}$ and $1.93 \mathrm{mg} / \mathrm{dl}$, ALP to $1168 \mathrm{U} / \mathrm{l}$, GPT to $704 \mathrm{U} / \mathrm{l}$, and T Bil to $2.2 \mathrm{mg} / \mathrm{dl}$ and $3.9 \mathrm{mg} /$ $\mathrm{dl}$, as shown in Figure 1. Elevated plasma uric acid $9.9 \mathrm{mg} / \mathrm{dl}$ (normal $2.4-6.0 \mathrm{mg} / \mathrm{dl}$ ), lower albumin level $2.7 \mathrm{~g} / \mathrm{dl}$ (normal 3.5 - $5.5 \mathrm{~g} / \mathrm{dl}$ ), and calcium $7.1 \mathrm{mg} / \mathrm{dl}$ (normal $8.4-10.4 \mathrm{mg} / \mathrm{dl}$ ) were also found. The following days of hospitalization, PT was slightly increased to 13.8 s. Because of this, an emergency cesarean section was performed on the 5th day of hospitalization and a healthy 2665 gm male baby was delivered. Her condition improved dramatically with lowering of AST to $34 \mathrm{U} / \mathrm{l}$, ALT to $62 \mathrm{U} / \mathrm{l}$, ALP to $747 \mathrm{U} / \mathrm{l}$, and T bil to $1.8 \mathrm{mg} / \mathrm{dl}$ (Figure 1). Direct bilirubin (D bil) was $0.7 \mathrm{mg} / \mathrm{dl}$ (normal 0 - $0.4 \mathrm{mg} / \mathrm{dl}$ ). Her postpartum condition was good in March 2011 with A1C 6.5\%. Fatty acid oxidation screening was normal in the baby. Her C-peptide level was $1.54 \mathrm{nmol} / \mathrm{l}$ in August 2011.

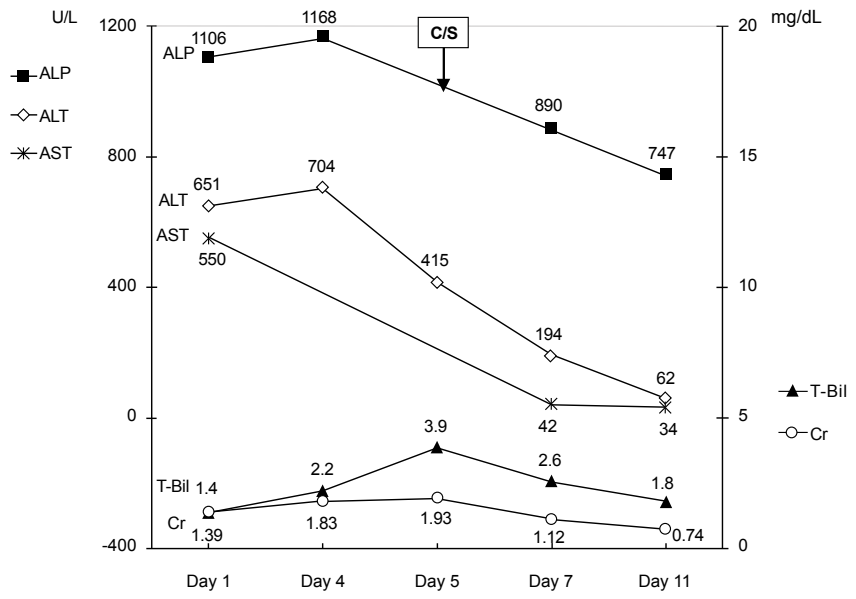

Figure 1:

*Corresponding author: Dr. Kwang-Wen Chen, Department of Internal Medicine, St Paul's Hospital, No 123, Chien-Hsin St., Taoyuan City, Taiwan, Tel: 8863-3613141; Fax: 886-3-3773373; E-mail: enjoy.kwangwen@gmail.com

Received February 21, 2012; Accepted April 22, 2012; Published April 26, 2012

Citation: Chen KW, Yang CC, Li YM, Lee YS (2012) Acute Fatty Liver of Pregnancy in a Woman with Type 2 Diabetes. J Diabetes Metab 3:185. doi:10.4172/2155 6156.1000185

Copyright: @ 2012 Chen KW, et al. This is an open-access article distributed unde the terms of the Creative Commons Attribution License, which permits unrestricted use, distribution, and reproduction in any medium, provided the original author and source are credited. 
Citation: Chen KW, Yang CC, Li YM, Lee YS (2012) Acute Fatty Liver of Pregnancy in a Woman with Type 2 Diabetes. J Diabetes Metab 3:185. doi:10.4172/2155-6156.1000185

Page 2 of 2

\section{Discussion}

This is a rare case of AFLP coexisting with type 2 diabetes and the first such case reported in Taiwan. There have been 18 patients with AFLP reported in a tertiary medical center in Taiwan over a 22-year period [4]. The diagnosis of AFLP in our case was made by typical history, symptoms and laboratory findings. There was no pathological confirmation by liver biopsy due to safety considerations and urgency for emergency delivery. We made the diagnosis of AFLP based upon the presence of at least 9 (vomiting, abdominal pain, elevated transaminases, elevated bilirubin, elevated urate, leucocytosis, polydipsia/polyuria, renal impairment, and coagulopathy) of the 14 criteria used in a previous report and absence of another explanation [6]. Diabetes insipidus occurring in AFLP has been reported in other reports $[7,8]$. However, how they are associated has not been well studied. The prognosis of AFLP is influenced by the interval between occurrence of AFLP and delivery [3]. Lower mortality was also found in mothers and babies following cesarean section as compared with vaginal delivery [3].

The mechanism of AFLP has not been fully elucidated. Natarajan et al. [9] reported that increased oxidative stress and accumulation of toxic mediators such as arachidonic acid were found in the placental mitochondria and peroxisomes of women with AFLP. Women with acute liver disease during pregnancy may have a genetic mutation in long-chain hydroxyacyl-CoA dehydrogenase (LCHAD). However, heterozygosity in the mother cannot alone account for the adverse effects and homozygous or compound heterozygous genetic defects in the fetus is the best known cause [10]. Nineteen percent of the offspring of women with AFLP might have LCHAD deficiency [11].

Screening of fatty acid oxidation including LCHAD with tandem mass spectrometry was performed and this was normal in our patient's baby. However, diverse etiological factors have been suggested in the Chinese population after genetic studies of LCHAD in proband and relatives [12]. Pathogenesis other than LCHAD still awaits further elucidation. Acute fatty liver can recur in subsequent pregnancies, even if LCHAD mutations are absent.

Although the association of non-alcoholic fatty liver (NAFL) with in type 2 diabetes has been reported [5], the association between AFLP and type 2 diabetes has not been previously reported as far as we know.
We describe this case to call more attention to the association of AFLP and type 2 diabetes.

\section{Acknowledgement}

We are grateful to Professor Wilfred Y. Fuji motor, University of Washington, for his review of this manuscript.

\section{References}

1. Knight M, Nelson-Piercy C, Kurinczuk JJ, Spark P, Brocklehurst P (2008) A prospective national study of acute fatty liver of pregnancy in the UK. Gut 57: 951-956.

2. Reyes H, Sandoval L, Wainstein A, Ribalta J, Donoso S, et al. (1994) Acute fatty liver of pregnancy: a clinical study of 12 episodes in 11 patients. Gut 35: 101-106.

3. Wei Q, Zhang L, Liu X (2010) Clinical diagnosis and treatment of acute fatty liver of pregnancy: a literature review and 11 new cases. J Obstet Gynaecol Res 36: 751-756.

4. Lau HH, Chen YY, Huang JP, Chen CY, Su TH, et al. (2010) Acute fatty liver of pregnancy in a Taiwanese tertiary care center: a retrospective review. Taiwan J Obstet Gynecol 49: 156-159.

5. Cusi K (2009) Nonalcoholic fatty liver disease in type 2 diabetes mellitus. Curr Opin Endocrinol Diabetes Obes 16: 141-149.

6. Ch'ng CL, Morgan M, Hainsworth I, Kingham JG (2002) Prospective study of liver dysfunction in pregnancy in Southwest Wales. Gut 51: 876-880.

7. Kennedy S, Hall PM, Seymour AE, Hague WM (1994) Transient diabetes insipidus and acute fatty liver of pregnancy. Br J Obstet Gynaecol 101: 387391.

8. Usta IM, Barton JR, Amon EA, Gonzalez A, Sibai BM (1994) Acute fatty liver of pregnancy: an experience in the diagnosis and management of fourteen cases. Am J Obstet Gynecol 171: 1342-1347.

9. Natarajan SK, Thangaraj KR, Eapen CE, Ramachandran A, Mukhopadhya A, et al. (2010) Liver injury in acute fatty liver of pregnancy: possible link to placental mitochondrial dysfunction and oxidative stress. Hepatology 51: 191200.

10. Wilcken B, Leung KC, Hammond J, Kamath R, Leonard JV (1993) Pregnancy and fetal long-chain 3-hydroxyacyl coenzyme A dehydrogenase deficiency. Lancet 341: 407-408.

11. Yang Z, Yamada J, Zhao Y, Strauss AW, Ibdah JA (2002) Prospective screening for pediatric mitochondrial trifunctional protein defects in pregnancies complicated by liver disease. JAMA 288: 2163-2166.

12. Kong XF, Zhang XX, Yu YY, Shi Q, La DD, et al. (2007) No mutation was found in the alpha-subunit of the mitochondrial tri-functional protein in one patient with severe acute fatty liver of pregnancy and her relatives. J Gastroenterol Hepato 22: 2107-2111. 